\title{
THE PHILOSOPHER-KING AND THE GREAT SAGE: A COMPARISON BETWEEN MARCUS AURELIUS' STOICISM AND CONFUCIUS' ETHICAL THEORY
}

\author{
Rocco A. ASTORE, \\ Adjunct Lecturer of Philosophy \\ CUNY: Borough of Manhattan Community College, \\ USA, \\ E-mail: rastore@bmcc.cuny.edu
}

\begin{abstract}
Within the history of world philosophies, there exist overlaps between individual thinkers, albeit removed by periods, and variance in location. As understood by this present writer, one of these intersections finds itself between the Stoic ideals of Marcus Aurelius as well as the ethical doctrines of Confucius. Although rarely explored, it is of interest to this essayist, to draw readers to consider how Aurelius' Stoic conception of arête or virtue, matches, or is the moral equivalent of the ethical conduct Confucius expounds in The Analects, specifically, the behaviors associated with those who are of the junzi. Afterward, this piece will then compare the idea of humaneness, or Confucius' concept of ren with Aurelius' cosmopolitan and humanist sayings, as found in The Meditations. Lastly, this piece will conclude by comparing Aurelius' and Confucius' shared fundamental outlook on morals and ethics, thus allowing us to assert that what they expounded possesses a similar appeal, helping to remove the barriers, dividing so-called "Western" and "Eastern" philosophical canons.
\end{abstract}

Keywords: Comparative Studies; Marcus Aurelius; Confucius; Stoicism; Confucianism; Ancient Philosophy;

\section{UNDERSTANDING AURELIUS' ARÊTE}

Aurelius' arête, as well as his cosmopolitan bent, provides readers with a glimpse into the mind of who this present author regards as perhaps being the closest embodiment of Plato's fabled philosopher-king; Marcus. Now, Aurelius, like many other Hellenistic and Greco-Roman thinkers, believed that virtue or arête defines as excellency, however to Aurelius, it is an excellency of character, and the purity to follow through with those pious intentions. ${ }^{1}$ In other words, arête, in the eyes of Aurelius, is not just about knowing what it is to be a right person; instead, it is also about being one. ${ }^{2}$

This Aurelian current of thought, that the importance of enacting an ethical, goodwill, is paramount in understanding his conception of arête. That is because when we refine ourselves, to focus in on how to execute our good intentions, through conducting ourselves ethically, we find that the goodness of our plans will translate into the benevolence of our acts. As such, we can never claim that we are failing to contribute to Aurelius' view of the common good. ${ }^{3}$ In other words, like Aurelius' Stoic belief, in testing our judgments via

\footnotetext{
${ }^{1}$ Aurelius, Marcus. The Meditations. Indianapolis: Hackett Publishing Co, 1983., 133.

${ }^{2}$ Ibid., 103.

${ }^{3}$ Ibid., 125
} 
hypothetical syllogisms, we can align our motives and behavior so that if we work toward community or the achievement of a familial reality between all, then such a bond can become real. $^{4}$

Next, although we may give credence to the idea that Aurelius believed Nature to be impersonal, it still works toward an end or a telos, and we, as means to Nature's dissemination throughout Earth, are to be virtuous, or full of arête. ${ }^{5}$ That is because people, as social, rational, and communicative, possess the ability to work or progress toward a community. In other words, as Aurelius would believe, we all play a role in life assigned to us by Nature. ${ }^{6}$ As such, we must embrace our destiny and trust that no matter what Providence may have in store for us, we can still lean on each other, or bear each other's burdens. $^{7}$

Thus, through endurance, we find tolerance. Through tolerance, we come to be compassionate and willing to assists those who are not as fortunate as we are, in temperament, or attitude toward life. Lastly, to make another allusion to Plato's Republic, we may claim that as people, it is not only our task to display our moral arête. It is also our task to emerge from the cave, alongside all those stuck in the cave, for humanity's. ${ }^{8}$ That is because we must do what is right for righteousness, which sets the cornerstone for the formation of the common good, to arise, as understood through Aurelius' Stoic vantage.

Now, this vision of the common good is achievable; ultimately, if all people embrace Aurelius' Stoic path of arête, which involves mastering the self, by accepting all that Nature, or Fate may throw at us. ${ }^{9}$ In other words, an element of being one who embraces Aurelian Stoicism is to remain calmly, or serenely indifferent, or unvexed by the ebb and flow of life. That is because, as Aurelius asserts, it matters not whether a governing Providence or Atoms or random particles acting in concert, rules the universe, it still we who have the power over our reactions. ${ }^{10}$ Consequently, we may assert that a degree of self-sufficiency, or the ability to quell or tame our inner thoughts and feelings, is in our possession, and we can use this artfully, or with arête, to perfect ourselves and inspire others to do the same. ${ }^{11}$

\section{AN EXPLICATION OF AURELIUS' COSMOPOLITANISM AND HUMANIST IDEALS}

From this conception of arête, we may now explore Aurelius' cosmopolitanism and humanist sentiments. First, by Aurelius' cosmopolitanism, we may enter one of the most famous quotes of The Meditations, in which Marcus states that as far as he is an emperor, he is a citizen of Rome; however, as a person, he is a citizen of the universe. Accordingly, we may claim that Aurelius is embracing two ideas at the same time. One notion conveyed by this aphorism is that Aurelius recognizes the importance of us all as people, or beings capable of reason and communication, and it is indeed our planet to protect, by accepting each other as elements needed for the continuity of our species. ${ }^{12}$

${ }^{4}$ Ibid., 131.

${ }^{5}$ Russell, Bertrand. The History of Western Philosophy. New York: Simon and Schuster, 1972, 254.

${ }^{6}$ Ibid.

${ }^{7}$ Aurelius, Marcus. The Meditations. Indianapolis: Hackett Publishing Co, 1983, 85.

${ }^{8}$ Plato. "The Allegory of the Cave". Los Angeles: Enhanced Media Publishing, 2010, 9-10.

${ }^{9}$ Aurelius, Marcus. The Meditations. Indianapolis: Hackett Publishing Co, 1983, 131-133.

${ }^{10}$ Ibid., 26, 31, 131.

${ }^{11}$ Russell, Bertrand. The History of Western Philosophy. New York: Simon and Schuster, 1972, 264-266.

${ }^{12}$ Aurelius, Marcus. The Meditations. Indianapolis: Hackett Publishing Co, 1983, 25-26. 
Simultaneously, we may understand Aurelius' maxim, as claiming that we are genuinely a fragment, or a small piece of what constitutes the natural order, the cosmos, or the universe in its fullness. ${ }^{13}$ As such, we must embrace our tininess in comparison to the awesomeness of Nature, and hence, recognize that we not only equally share in our responsibility and duty to our social or political communities. Instead, we also share in the notion that we are all members of the same cosmic system, without exception. ${ }^{14}$ For, we, by being of this planet, are also of this galaxy, which is part of the one natural order, in which we all reside. ${ }^{15}$ Accordingly, it is the opinion of this present essayist that Aurelius would at least implicitly assert that no one person is better than another and that we all play a part in the overall scheme of existence.

One way to view or envision Aurelius' humanist leanings is by analyzing what living in accordance with Nature, and its impersonality means. Now, to live in agreement with Nature we must first withhold assent to any judgment until we find that what we are appraising is certainly good or bad, and not indifferent. ${ }^{16}$ In other words, to Aurelius, although a benevolent Providence guides, or governs the natural order, it is still for us to discover its purpose for us in life, and since we always fail to match its magnitude, bars us from being in direct communication with Nature.

That is because much like how it is that aquatic life relies on water to subsist. While, in contrast, water does not rely on what it shelters for its continuation, we may claim that the benevolence or care of Nature is in the fact that it is eternal. At the same time, Nature is ceaselessly fleeting, while still providing a chance to be, to all that inhabits it. Thus, Nature, to Aurelius, by giving us all a home to develop and perfect ourselves, via Stoic theory and practice, equally grants us all the potential to achieve such perfection, rendering it to be compassionate enough. Lastly, since we all inhabit Nature, and because Nature's disinterested goodness is adequate for us all to master ourselves, it is indeed we who have each other to cope with in life. Hence, it is we who must live with goodwill toward one another. ${ }^{17}$

Next, for us to achieve such humanism, equality, and goodwill toward each other, it is paramount to address Stoic assent and how the refraining from judging too quickly whether a thing or being is good or bad, helps to practice indifference, acceptance, and decency toward all. ${ }^{18}$ That is because through practicing withholding our decisions, until we are sure of them, we assist ourselves in strengthening our directing-minds, or that facet of our minds which ultimately is responsible for whether we assent to a thing as being excellent, bad, or indifferent. ${ }^{19}$ From this, we may claim that it is when we refrain from judging too hurriedly, that we cultivate humaneness, in the form of practicing patience. Lastly, this power of perseverance not only helps us to bear the shortcomings of others, it also helps to condition us in such a way that we welcome dealing with others' flaws. For, we know by doing so we will make our power of patience more formidable.

\section{CONFUCIUS' CONCEPTS OF JUNZI AND REN: HUMANIST IMPLICATIONS}

Upon entering the philosophy of Confucius, we come to find two key concepts that are central to comprehending the Confucian project in its entirety. That is, we come to see

\footnotetext{
${ }^{13}$ Ibid., 30-31.

${ }^{14}$ Ibid., 25-26.

15 Ibid.

${ }^{16}$ Ibid., 116-117.

${ }^{17}$ Ibid., 85.

${ }^{18}$ Ibid., 131-133.

${ }^{19}$ Ibid., 131-135.
} 
the notions of the junzi, and the humaneness practiced by those who are of the junzi; the goodness of ren. Now, by junzi, Confucius understands those who are of a superior brand of people. ${ }^{20}$ In other words, the junzi are those who practice the ethical code of selfless service, compassion, kindness, and the acceptance of all people, which derives from their self-chosen moral code. ${ }^{21}$ This self-chosen ethic, to Confucius, is benevolent when it helps one who adheres to traditional devotion, ritual, and filial piety, or the maintenance of respect between the older and younger members of our families, to actively pursue the spreading of adoration to all they encounter. ${ }^{22}$ Thus, we find that in Confucianism, those who embrace their humanity, are those who are on the path of the junzi, and it is this way of living that is most in line with Confucius' version of Tao. ${ }^{23}$ Lastly, this Tao is not so much the force that we are to submit to and embrace as a means to living most fluidly, or least obtusely. Instead, in Confucian theory, the Tao is the active maintenance of the way of social harmony, which prevails when the junzi uphold the standard of ren. $^{24}$

That is because the term ren, we can understand as the maxim or principle, or that voluntary choice of allowing ourselves to acknowledge that we can be better people, through strictly following, in our day-to-day lives, a mode of righteousness that suits us. ${ }^{25}$ In other words, it is not that Confucius believes that every different path aside from his, fails to attain the status of ren. Instead, all ways constituting goodness include acceptance on our part, to adhere to standards of conduct that never fail to bare benevolence toward all others. ${ }^{26}$

Therefore, let us confidently assert that the junzi, who practice the virtue of ren, are indeed practicing a humanistic moral outlook via their ceaseless ethical decorum. ${ }^{27}$ That is because, much like Kant, who outdates Confucius by over two-thousand years, Confucian philosophy expounds acceptance on the part of autonomous individuals, like the junzi, to practice ren, or a kind-heartedness that maintains the respect of all individuals they meet. ${ }^{28}$

Thus, this virtue, to be able to embrace a freely chosen moral maxim, or ren, which maintains the dignity of every person, due to our shared humanity, assists us in recognizing that this aspect of the junzi, rings oddly modern. For, ren, as the moral principle behind the ethical behavior of the junzi, allows us to claim that the genuinely morally superior person, is one who embraces the value of all humanity. ${ }^{29}$

Finally, this high regard for all human life, as harbored by the junzi, maintains social harmony for the benefit of governments, which we shall now explore. Now, upon turning to Confucius' The Analects, we come to find an underlying current of thought, namely, the idea that we must work toward a common good, or social harmony through social reform. ${ }^{30}$ This idea of social harmony via social change starts with the reformation of the self, of which we are all capable. ${ }^{31}$ That is, Confucian philosophy does not rest on a source outside of ourselves, to validate Confucius' sayings; instead, it is solely we who are responsible for

\footnotetext{
${ }^{20}$ Confucius. The Analects. Oxford: Oxford University Press, 2008, xviii-xix.

${ }^{21}$ Ibid., 3 .

22 Ibid.

${ }^{23}$ Ibid., xxiv-xxv.

${ }^{24}$ Koller, John M. Oriental Philosophies. New York: Charles Scribner's Sons, 1970, 246, 263-264.

${ }^{25}$ Confucius. The Analects. Oxford: Oxford University Press, 2008., xxi-xxii.

${ }^{26}$ Ibid.

${ }^{27}$ Koller, John M. Oriental Philosophies. New York: Charles Scribner's Sons, 264-266.

${ }^{28}$ Confucius. The Analects. Oxford: Oxford University Press, 2008, 44.

${ }^{29}$ Ibid.

${ }^{30}$ Koller, John M. Oriental Philosophies. New York: Charles Scribner's Sons, 250-252.

${ }^{31}$ Ibid.
} 
concretizing the reality we wish to share with others. ${ }^{32}$ One way in which we can achieve social harmony, via social reform, is by practicing the Confucian maxim that we should not do unto others what we would not want to experience ourselves. ${ }^{33}$

Again, here we find Confucian philosophy strikingly foreshadowing later religious philosophies associated with the "West." In other words, much like the famous Golden Rule expounded in the Gospels of Christianity, some five-hundred years later, Confucius, too, believes that upright moral principles, or real ren, is necessary for accord between people. ${ }^{34}$ Lastly, as a reminder to readers, it is this accord which is the bedrock of righteousness that is mandatory for the solidarity of the masses, needed to conduct human government, which, again, starts with a reformation of the self for the highest good in social milieus.

Furthermore, this social coherency, produced by our resolve to be better people, or to properly constitute our membership to the junzi, centers on the idea that together we can all contribute to the continuation of human society, and as such, truly preserve our world for ourselves, while future generations that will come to inhabit our communities. ${ }^{35}$ In other words, Confucian philosophy focuses us on maintaining ourselves for the benefit of others, both now, and for those to come, and it is this current of ideas that permeates The Analects. As such, we find that this potential power to preserve existence depends on us, for we possess the means to treat all people we encounter as worthy or entailing the dignity and recognition of those deserving of the title of junzi.

Thus, we may assert that by preserving the present, which we all share as conscious beings, assists us in realizing that if we continue to maintain ourselves and our societies, then it is sure that we can progress into a harmonious future. Lastly, let us now enter a comparison between Aurelius' Stoicism and Confucian morality, and by doing so, assists in showing that the boundaries between so-called "Western" and "Eastern" philosophical thought, is not as stark as we may believe it to be, initially.

\section{COMPARING AURELIUS AND CONFUCIUS:}

\section{SMASHING A BARRIER BETWEEN THE "EAST" AND "WEST":}

Now, one striking similarity between the philosophies of Aurelius and Confucius is that they regard the individual as paramount in achieving the common good of all. First, let us note that we should not so much understand Aurelius and Confucius as believing that one person can change the entirety of society. Instead, Aurelius and Confucius are expounding theories which claim that it is in the potential of all people to achieve the common good by starting with who they are and making themselves benevolent by pushing themselves always to be and do better. Hence, we may claim that one similarity between the philosophies of Aurelius and Confucius is that both ascribe to the view that people can perfect themselves. From this pursuit of perfection, or the idea that people can work towards manifesting the world that we all would like to live in, to be a genuine reality, shows that the most significant human good, peace, and prosperity, is central to the thinking of Aurelius and Confucius.

Confucius' notion of ren and Aurelius' understanding of arête, are similar concepts to say that least. One reason why this present writer makes this claim is that arête or moral excellency through the practice and application of such virtue, links to ren which is the ethical principle of uprightness that we are to practice, perpetually, as found in

\footnotetext{
${ }^{32} \mathrm{Ibid}$.

${ }^{33}$ Confucius. The Analects. Oxford: Oxford University Press, 2008, 44.

${ }^{34}$ Ibid., xiii, xxi-xxii.

${ }^{35}$ Ibid., xviii-xix.
} 
Confucianism. ${ }^{36}$ That is, both ren and arête, are modes, or ways of goodness that we are to embrace, so that we may come to call ourselves real Stoics, as Aurelius would assert, as well as sincere junzi, or the superior individuals that Confucius has in mind. ${ }^{37}$ Thus, we may claim that the virtues associated with arête, such as, love for our fellow people, and the decorum and compassion umbrellaed by the concept of ren, shows that Aurelius' understanding of a Stoic, and Confucius' vision of the junzi are not disparate. ${ }^{38}$ Moreover, although we encounter the idea of the Tao in Confucian Thought, and the reality of Nature in Aurelius' Stoic reflections, we find that both philosophers support the understanding that it is we, who, in part, objectify such metaphysical notions. ${ }^{39}$ In other words, both Aurelius' Stoic comprehension of Nature and Confucius' envisioning of the Tao consists in the fact that it is we who grant life to these ideas, by making them real through our ethical conduct. ${ }^{40}$

That is because Nature, or the Tao, are conceptions that guide us or imply what we are to perform for ourselves, to be exemplary servants of humankind, and it is in our hands to make those implications real. ${ }^{41}$ Finally, it is from these moral hints, or the tacit understanding of how we are to treat others and behave in life, that we are to follow, ceaselessly. For, in Confucianism and Aurelius' Stoicism, the more that we hone who are, the better we can provide for others, and the better we can provide for others, the more we strengthen our political communities. ${ }^{42}$ Furthermore, another parallel that exists between Aurelius' and Confucius' moral and ethical image of humanity is that both philosophers believe that respecting others is paramount for the progress of our co-existence. In other words, much like how it is that Aurelius believes that our shared humanity should assist us in realizing that we are all of a single "government," fated by one providential universe. Confucius also understands that we must continually refrain from infringing on others, so that we may preserve the one true Tao of the state, of which we all partake. ${ }^{43}$ That is because Aurelius, and especially Confucius, would understand that it is when we overstep the boundaries of proper everyday societal conduct, or traditions, that we foster the decay, or disintegration of the fabric which holds our social milieus together, i.e., the state. ${ }^{44}$ Thus, we may assert that if we fail to remain respectful, then we fail to express genuine compassion, and if we cannot convey compassion, then we cannot co-exist. Now, without co-existence, the reality of community would cease, and if a community were to cease, the state would be impossible to manifest or achieve. However, the reality of political states implies that Nature, as Aurelius would call it, or the Tao, as Confucius would declare it, intends for us to live in harmony. Therefore, we may safely assume that Aurelius and Confucius aim for the individual to be righteous, so that that person may carry the weight of others when required,

\footnotetext{
${ }^{36}$ Aurelius, Marcus. The Meditations. Indianapolis: Hackett Publishing Co, 1983, 131-133 \& Confucius. The Analects. Oxford: Oxford University Press, 2008, xxi-xxii.

${ }^{37}$ Ibid.

${ }^{38}$ Ibid.

${ }^{39}$ Aurelius, Marcus. The Meditations. Indianapolis: Hackett Publishing Co, 1983, 131-133 \& Confucius. The Analects. Oxford: Oxford University Press, 2008, xxiv-xxv.

${ }^{40}$ Ibid.

${ }^{41}$ Ibid.

${ }^{42}$ Aurelius, Marcus. The Meditations. Indianapolis: Hackett Publishing Co, 1983., 121 \& Confucius. The Analects. Oxford: Oxford University Press, 2008, 50.

43 Aurelius, Marcus. The Meditations. Indianapolis: Hackett Publishing Co, 1983., 26-27 \& Confucius. The Analects. Oxford: Oxford University Press, 2008, xxiv-xxv.

${ }^{44}$ Aurelius, Marcus. The Meditations. Indianapolis: Hackett Publishing Co, 1983., 26-27 \& Confucius. The Analects. Oxford: Oxford University Press, 2008, 44.
} 
and that that selflessness paves the way for such community, or social bonds, which, in turn, composes a unit of co-existence. i.e. a political state. ${ }^{45}$ From these considerations, we may find that Aurelius and Confucius were not so unalike as we may assume them to be, due to their separation in time and location. That is because of this essayist casting light on the fact that Confucius' understanding of ren, and the junzi, matches well with Aurelius' Stoic sentiments, including the concept of arête ${ }^{46}$ Lastly, it is the hope of this present writer that by this comparison between Aurelian and Confucian philosophy, we may more readily understand that the divisions between "Western" and "Eastern" thought is not as discordant as we may believe, especially on first glance.

\section{CONCLUSION}

Despite being apart by both time and place, we nevertheless find that Aurelius and Confucius shared an affinity for channeling humanity to secure the common good for all. That is, throughout The Meditations and The Analects, we encounter a strong current of thought which fortifies and purports that the unity of humanity outweighs the deterioration of society. As such, it is the role of us all to extend the safety of life, as long as possible. Thus, we claim that the purpose of this piece was not only to show how Aurelius and Confucius shared in a similar outlook on the purpose and meaning of humanity. Instead, this article also aimed to display how what we may take to be a division in space and time is not so disparate at all. First, to secure such an outlook, this present writer drew from Aurelius' understanding of arête and juxtaposed it with Confucius' notions of the junzi and ren, to show how these concepts are genuinely alike in their importance to both thinkers, regarding humankind. Next, this essay guided readers to consider the similarities between Aurelius' cosmopolitanism and humanism, as well as the humanism of Confucius. Lastly, through a direct comparison between Aurelius and Confucius, it was the intention of this piece and its present writer to assists in breaking the barrier we usually assume that exists between socalled "Western" and "Eastern" philosophical styles of thinking.

\section{BIBLIOGRAPHY}

[1] Aurelius, Marcus. The Meditations. Indianapolis: Hackett Publishing Co, 1983.

[2] Confucius. The Analects. Oxford: Oxford University Press, 2008.

[3] Koller, John M. Oriental Philosophies. New York: Charles Scribner's Sons, 1970.

[4] Plato. "The Allegory of the Cave". Los Angeles: Enhanced Media Publishing, 2010.

[5] Russell, Bertrand. The History of Western Philosophy. New York: Simon and Schuster, 1972

\footnotetext{
45 Aurelius, Marcus. The Meditations. Indianapolis: Hackett Publishing Co, 1983., 83 \& Confucius. The Analects. Oxford: Oxford University Press, 2008., xxi-xxii.

${ }^{46}$ Aurelius, Marcus. The Meditations. Indianapolis: Hackett Publishing Co, 1983., 131-133 \& Confucius. The Analects. Oxford: Oxford University Press, 2008., xxi-xxii, xxiv-xxv.
} 